\title{
Elisa Fortunato
}

\section{Translating Swift: Censorship and Self-Censorship during Fascism}

\begin{abstract}
This article studies censorship and self-censorship during the Fascist regime in Italy and the fine boundary between the two. It focuses, in particular, on the accuracy and adequacy of translations of Gulliver's Travels in Fascist Italy, and analyses how responses to the Fascist "revision" system changed depending on law, patronage, and the material circumstances in which the translators worked. By examining the translations published during the regime, we can identify different translation strategies that can be interpreted respectively as acts of submission to or resistance against the dominant way of thinking.
\end{abstract}

Keywords: novel, translation, Swift, Jonathan, Italy, censorship

Censorship is a practice undertaken by a given society at a given moment in time. It materializes either through repressive cultural, aesthetic, and linguistic measures or through economic pressure (Billiani 2007). In this article, I will discuss a less blatant form of control, that peculiar phenomenon of self-censorship which took place in Italy during the first decade of Fascist domination, before the promulgation of the racial laws (1938), when censorship became overt and coercive. In particular, I will analyse the first two translations of the full text of Gulliver's Travels by Jonathan Swift, which, interestingly, were issued during the Fascist regime (in 1933 and 1934 respectively). In fact, I believe that a lack of critical analysis, stemming from the fact that Swift was a foreigner and the work was a classic "universally recognized as such" (as we read in a circular from the Minister of Popular Culture, Dino Alfieri, to the prefects), ${ }^{1}$ left the way open for translations in first unabridged versions.

1 "I. A datare dal 10 aprile c.c. soltanto questo ministero potrà autorizzare la diffusione in Italia delle traduzioni straniere; II. Gli Editori possono inviare a questo Ministero direttamente o a mezzo della Prefettura, nella lingua originale, i libri che intendono tradurre in italiano; III. Questo Ministero farà conoscere all'Editore - tramite la Prefettura competente - il suo giudizio nel termine più breve; [...] V. Sono esclusi dalla preventiva approvazione i trattati puramente scientifici (medicina-ingegneria-matematica-astronomia-botanica-zoologia) e i classici universalmente riconosciuti" [I. From 1 April of this year only this Ministry may authorize the diffusion of foreign translations in Italy; II. Publishers may send in the original language those titles they intend to translate into Italian directly to this Ministry or through the Prefecture; III. The Minister will notify 
Analysing the multifaceted nature of censorship, I will try to bridge the gap between linguistic analysis and cultural history. In so doing, translation will be seen not only as a historical object but also as an approach to interpreting a historical subject (Rundle 2014); our case study will shed light on Italian cultural history. During the Fascist regime, translations became a political matter and they were framed in terms of a trade war. The common political discourse made reference to the import and export of intellectual products and to the balance which needed to be adjusted in favour of Italian intellectual production. More generally, the regime was "disturbed by the idea of Italy being an excessively receptive culture, with an exaggerated enthusiasm for all things coming from abroad, and translations were the threatening sign of its own weakness" (Rundle 2010, 5): available data show that Italy published more translations than any other country in the world at the time, and that translations from English tripled between 1933 and 1934 (Bonsaver 2007; Rundle 2010). Despite these worries, however, the regime was unwilling to stop the translation industry because it could have caused the exclusion of Italy from international debate and from a growing field of business activity.

The Italian Fascist dictatorship therefore had an ambiguous attitude towards translations. According to the famous magazine of the publishers' association, $I l$ giornale della libreria, in 1932 the three pillars of the Italian autarchy were "valorizzazione e potenziamento libri e periodici, esclusione oculata secondo i fini dell'interesse nazionale, assorbimento di tutte le attività, anche se provenienti dall'estero, che possano contribuire alla realizzazione della società moderna" [to give value and power to books and magazines, to exclude things carefully according to the national interest, and to absorb all activities, including those coming from abroad, which could contribute to realizing modern society] (printed in Billiani 2007, 19-20; my translation). Translating novels became a way to "absorb" and "include" the Other into Italian Culture, a way to (using Bassnett's term) "cannibalize" it.

It is possible to divide, broadly speaking, the period from 1929 to 1943 into two phases. In an initial phase, although there was some disapproval at the influx of foreign literature, the regime neither cared enough nor was organized enough to attempt to hinder the rapidly increasing inflow. In a second phase, from 1935

the Publisher - through the appropriate Prefecture - of its judgement with the shortest possible delay; [...] V. Purely scientific treatises (in medicine, engineering, mathematics, astronomy, botany, and zoology) and classics universally recognized as such are exempt from prior approval] (circular no. 1135, issued on 26 March 1938 by the Minister of Popular Culture, Dino Alfieri, printed in Fabre 2007, 27-28; my translation). 
onwards, the Press Office became the Ministry for the Press and Propaganda and Censorship, and repression of freedom became more and more widespread; this phase culminated in 1938 with the introduction of the Fascist racial legislation.

The two translations I examine in this article, which largely fail to reproduce Swift's rhetorical art, were published in 1933 and 1934. It is my belief that they found room in the Italian translation industry because they were issued before the increase in surveillance, and also because, during the twenty years of Fascist autarchy, interest in foreign literature decreased, and, as a consequence, the web of censorship was less impenetrable. Studying the history of translations of Gulliver's Travels has the potential to help us understand the apparently contradictory system of surveillance and punishment implemented under the Fascist regime.

The history of the reception of Jonathan Swift's Gulliver's Travels in Italy has its roots in the eighteenth century. "The early reception of Swift in Italy was part of a growing veneration for the politics, the economy, the arts and literature of Great Britain, a new phenomenon unheard of in previous centuries that goes under the name of 'anglomania'” (Gregori 2013, 17). The first translation of Gulliver's Travels was issued in 1729 by the Venetian printer Giuseppe Corona, who published the first two books of the Viaggi del Capitano Lemuel Gulliver in diversi paesi lontani. The translator, Francesco Manzoni, relied on the French translation by Desfontaines (Pagetti 1971, 20), Le voyages de Gulliver. This was a translation totally devoted to its French readers, by Desfontaines's own admission:

\footnotetext{
Vous trouveréz Monsieur en beaucoup d'endroits une traduction peu fidèle; mais tout ce qui plaît en Angleterre n'a pas ici le même agrément, soit parce que les moeurs sont differentes, soit parce que les allusions et les allégories, qui sont sensibles dans un pays, ne le sont pas dans un autre: soit enfin parce que le gout des deux Nations n'est pas le même. Jai voulu donner aux François un Livre qui fut a leur usage; voila ce qui m'a rendu Traducteur libre et peu fidèle. J'ai même pris la liberté d'ajouter, selon que votre imagination échauffoit la mienne. (Woolley 1999, 109-110)
}

[You will find, in many places, an inaccurate translation; but all that pleases in England does not give the same pleasure here, either because the manners are different, or because the allusions and allegories, which are agreeable in one country, are not in another: finally because the taste of the two nations is not the same. I wanted to give the French a Book which was for their use; here is what made me a free and untruthful translator. I even took the liberty of making additions, when your imagination warms up mine.] (my translation)

Desfontaines and Manzoni omitted or summarized the scatological details that occur throughout the work, and put a strong effort into rendering the bitter style of Swift into a smooth and pleasant French and Italian.

During the eighteenth century, all the following translations of Gulliver's Travels into Italian appear to be incomplete as well, deprived of the peculiar Swiftian 
stinging satire and sharp humour, and all lacking the last book, "A Voyage to the Country of the Houyhnhnms": "The eighteenth-century fortune of Swift in Italy is appropriately summarized in the remarks of Matteo Borsa's Del gusto presente in letteratura italiana (Of the Present Taste in Italian Literature, 1784), a study of the decline of literary taste in Italy and its reasons" (Gregori 2013, 33). As a consequence, during the nineteenth century, the Italian interest in Swift decreased dramatically; there was no room left for prose satire in a country where the "Romantic rejection of Neoclassicism, and of eighteenth-century aesthetics and standards of taste, implied the refusal of those authors not held as 'universal', and Swift was perhaps too topical not to be included in the demise of those standards" (Gregori 2013, 35).

Throughout the nineteenth century, abridged translations of Gulliver's Travels were used as a didactic tool in schools in order to teach the English language. As a consequence, Gulliver's Travels became a classic of children's literature, losing all of its original crushing force: Gulliver's Travels was downgraded to mere children's literature. On the other hand, however, it has to be underlined that, during the nineteenth century, the first direct translation of Gulliver's Travels was released by Gaetano Barbieri in 1842. Furthermore, it must be noted that, at the end of the century, the critics start to show an admiration for Swift's work, even if most of them, as the long essay I pessimisti [The Pessimists] by Andrea LoForteRandi shows, linked their reading of Swift's work to his private life and biography. Nevertheless, it is interesting that it is at the end of the nineteenth century that Gulliver's Travels starts to be considered a masterpiece rather than a mere work for children (Gregori 2013, 38-39). From then on, Gulliver's Travels would become a novel to be read by children and adults in its entirety.

The twentieth century was the epoch of a renewed interest in Swift's work as a whole. Almost all of his pamphlets, essays, poems, and novels were translated. Of course, Gulliver's Travels remained the most translated and studied of his works. "The industry of transforming Gulliver's Travels into a classic for children carried on well into the century, in some instances producing poor quality, in others with good or at least satisfactory results" (Gregori 2013, 39). What is most interesting is that the fourth book was always cut off; its bitter and misanthropic message was too much for a Catholic educational system (Pagetti 1971, 232). "In this process, Gulliver's Travels was literally split into two works, one playful and fabulous, and therefore fit for children, and the other satiric, and therefore to be expunged" (Gregori 2013, 40).

In 1913, Aldo Valori released the first unabridged Italian translation of Gulliver's Travels. His translation was a manipulating one, totally devoted to a strategy of amplification, diffusion, and unnecessary reordering. Many passages in Valori's version show a close link with Desfontaines's translation, often overlooking 
the source text in the process. It is very likely that Valori used both the English original text and Desfontaines's French version in order to sweeten some harsh passages, and that he chose to follow the "French hypotactic syntax and punctuation instead of the more paratactic English" (Gregori 2013, 42).

If, on the one hand, the twentieth century was the century of translations of Swift (A Modest Proposal, An Argument against Abolishing Christianity in England, A Meditation upon a Broomstick, The Art of Political Lying, A Tale of a Tub), it was, on the other hand, the century of a lack of critical studies of Swift's work.

According to Pagetti $(1971,172)$ and Gregori $(2013,42)$, the preface of Prezzolini's translation of $A$ Full and True Account (Una vera fedel narrazion di quell che avvenne in Firenze) could be considered the starting point of Swift criticism in Italy during the twentieth century. In his preface, Prezzolini underlines how the biographical details of Swift's own life were less interesting than his prose, and he concentrates his analysis on Swift's prose style and ideas. Flavio Gregori, in his illuminating article "The Italian Reception of Swift," lists a series of critical studies that appeared during the first decade of the twentieth century: from Prezzolini's preface to Papini's review of Valori's translation, from Adolfo Faggi's essay (1913) to Rabizzani's essay (1914) and Rebora's monograph (1922) on Swift's work (the first Italian monograph totally devoted to the Dean's work). In particular, Gregori focuses on Rebora's critical study, noting that "Rebora's merit lies in his knitting together the various biographical, cultural, and contextual trends of early Italian studies of Swift, showing also a better knowledge of the English critical tradition" (Gregori 2013, 44).

In line with the first decade of critical studies of Swift's work, during Fascism “critics showed less interest in Swift than publishing houses" did (Gregori 2013, 44). It is my belief that the few critics who studied Swift ${ }^{2}$ misread Gulliver's Travels because of its criticism of England. This myopic reading, combined with a lack of critical analysis, would have provided a context for translating the novel and publishing the first two unabridged Italian versions of it.

In 1933, Mondadori published Carlo Formichi's translation of Gulliver's Travels. "Formichi's text is more accurate than any published before and may well be said to be the first Italian version of Gulliver's Travels based exclusively on the English original" (Gregori 2013, 45). It comes as no surprise that Mondadori was the publisher of Formichi, both because Arnoldo Mondadori was one of the most active publishers in creating a "translation market" in Italy and because Monda-

2 "Esther Martini (1933) produced an unimpressive monograph, advocating a moralistic, almost prudish, interpretation. Tarquinio Vallese's more academic study (1933) of the English humorists repeats the routine opinion of Swift's lack of humour" (Gregori 2013, 48). 
dori openly supported Fascism and enjoyed good relations with the regime. Formichi has an admirable mastery of both languages, although he tempers the text's satirical sting, which was not in line with the Fascist cultural project, which aimed to create the image of a refined Italian taste that was not to be filthy, vulgar, or contain excessively vivid descriptions.

The second complete translation was by Luigi Taroni, published in 1934 by the Barion publishing house. It was worse than Formichi's translation, and it reprints an abbreviated version of Scott's biographical introduction. The Barion publishing house was a small publisher founded in 1908 with the aim of publishing cheap popular fiction and children's literature using new production and distribution methods. This was in line with the Fascist objective of dismantling the ivory tower in which intellectuals had, according to Fascist rhetoric, always confined themselves. This translation of Gulliver's Travels is part of this policy (a cheap edition of a classic "universally recognized as such," published for children and adults).

Taroni, in tune with the spirit of Fascism, chooses a domesticating translation strategy. Following Formichi's translation, he changes Swift's eighteenth-century lexicon by using a plain twentieth-century Italian, and rephrases the peculiar Swiftian parataxis into an orderly Italian hypotaxis. He never demands an effort from his twentieth-century Italian reader, and thus any distance in time and space is brutally erased. Taroni translates names and surnames, losing all the puns and word-plays which are fundamental to Swift's curious novel. For example, at the very beginning of the first book, Gulliver gives an account of himself and his family, saying that the Emmanuel College boarding costs were too expensive for his family and so he "was bound Apprentice to Mr James Bates, an eminent Surgeon in London.” From now on, Mr James Bates will be called Mr Bates and, in doing so, the writer creates an play on words with English masturbates that becomes explicit a few lines later: "But, my Good Master Bates dying two years later" (Swift 2012, 29-30). Taroni translates "Mr" with the closest Italian equivalent, "signor" (Swift, trans. Taroni 1934, 30), while Formichi is much more accurate, leaving the man's English title but not dare, when he dies, to translate his death as "con la morte del mio buon maestro due anni dopo” (Swift, trans. Formichi 1933, 12), omitting the surname "Bates."

One of the many examples of such attempts to temper Swift's lexical choices and vivid imagination can be found in the second book, when Gulliver is among the giants. Being infinitely smaller than his "hosts," he can easily see the lice on the beggars he meets in the capital city of this imaginary country: "I could see distinctly the Limbs of these Vermin with my naked Eye [...] and their Snouts with which they rooted like a Swine" (Swift 2012, 159). Taroni chooses not to translate the verb root, which evokes at once the idea of smelling and digging, and thus 
makes the description particularly disgusting: "avevano il muso simile a quello di un maiale" (he at least keeps the alliteration of "Snouts" and "Swine" with "muso" and "maiale"; Swift, trans. Taroni 1934, 139). Formichi, instead, sacrifices the repetition of the $s$-sound but keeps the disgusting image of lice that eat the beggars' skin: “e come si vedevano i loro grifi con i quali, a mo' di porci, andavano scavando," with the periphrastic conjugation showing a never-ending repugnance (Swift, trans. Formichi 1933, 155). Swift goes on: "the Sight was so nauseous, that it perfectly turned my Stomach" (Swift 2012, 169). Taroni softens this sentence, possibly considering the bon goût of his readers ("e poi il loro aspetto mi rivoltava tanto, che forse questa operazione sarebbe stata superiore alle mie forze"; Swift, trans. Taroni 1934, 139), while Formichi opts for a more formal Italian register with the verb recere instead of vomitare and, in so doing, succeeds in being faithful both to the source text and to his readers (Swift, trans. Formichi 1933, 159).

Another example of how Formichi and Taroni dilute Swift's harsh satire and sordid details is in book four, where Gulliver, talking with the Master of the intelligent horses, describes the English nobility:

\begin{abstract}
That Nobility among us was altogether a different Thing from the Idea he had of it; That our Young Noblemen are bred from their Childhood in Idleness and Luxury; that as soon as Years will permit, they consume their Vigour, and contract odious Diseases among lewd Females; and when their Fortunes are almost ruined, they marry some Woman of mean Birth, disagreeable Person, and unsound Constitution, merely for the Sake of Money, whom they hate and despise. That the Productions of such Marriages are generally scrophulous, rickety, or deformed Children, by which means the Family seldom continues above Three Generations, unless the Wife takes care to provide a healthy Father among her Neighbours, or Acquaintance, in order to improve and continue the Breed. That a weak diseased Body, a meager Countenance, and sallow Complexion, are no uncommon Marks of a Great Man; and a healthy robust Appearance is so far disgraceful in a Man of Quality, that the World is apt to conclude his real Father to have been one of the Inferiors of the Family, especially when it is seen that the Imperfections of his Mind run parallel with those of his Body and are little else than a Composition of Spleen, Dulness, Ignorance, Caprice, Sensuality, and Pride. Without the Consent of this illustrious Body, no Law can be enacted, repealed, or altered: And these Nobles have likewise the Decision of all our Possessions without Appeal. (Swift 2012, 385387 ; italics in original)
\end{abstract}

If Formichi is accurate in translating this passage - even if he opts for easy-toread direct speech instead of the free indirect speech of the source text (Swift, trans. Formichi 1933, 372) - Taroni uses a colloquial Italian and removes the whole passage concerning sexual intercourses and related diseases: "Gli dissi poi che la nostra libertà era molto diversa da quel che si era immaginato: che i nostri giovani nobili erano fin dall'infanzia allevati nell'ozio e nel lusso e che il carattere distintivo di questa classe era un impasto di malinconia, di stupidità, di ignoran- 
za, di incostanza, di sensualità, di albagia" (Swift, trans. Taroni 1934, 311). ${ }^{3}$ Moreover, in this quotation, we find a typical Swiftian series: "ignorance," "pride," "caprice." Swift creates a cohesive web through the repetition of a lexical series. The two translators mistakenly believe that Swift's word-catalogues are part of the eighteenth-century urge to compile and, as a consequence, do not care much about keeping Swift's repetitions, whereas the number of series in Swift, being twenty times that in Defoe, Addison, or Steele (Milic 1967, 88-89), shows his desire to mock their style, their urge to compile. If Defoe's style is proverbial for its plainness, Swift's is a satire of that plainness. He dismantles the rules of the novel from within.

Finally, an interesting example of how the lack of critical studies led to a misinterpretation of Swift's purpose can be found in book 1, when Gulliver decides to extinguish the fire in the Lilliputian Royal Palace by urinating on it. In Swift we read: "her Imperial Majesty's Apartment was on fire, by the carelessness of a Maid of Honour, who fell asleep while she was reading a romance” (Swift 2012, 79). Taroni (Swift, trans. Taroni 1934, 54) translates "romance” using Desfontaines's version, "poeme Blefuscudien" (Blefuscu was intended as the satirical portrait of the Kingdom of France). Formichi (Swift, trans. Formichi 1933, 67), on the other hand, uses the Italian "romanzo" as if it were a hypernym, without stressing the difference between novel and romance. But it is not by chance, I believe, that Swift chooses the word "romance" rather than "novel." He is satirizing the "fictitious narrative in prose of which the scene and the incidents are very remote from those of ordinary life." 4 Taroni's and Formichi's translations thus show a lack of understanding of Swift's satirical bite.

Overall, Formichi reveals himself to be a braver and more accurate translator than his colleague. Both of them, however, do not translate the two paratextual elements of the novel: the preface, "The Publisher to the Reader," and the "Letter from Captain Gulliver to his Cousin Sympson.” These elements were both written by Swift but signed respectively by the imaginary Richard Sympson - Gulliver's cousin - and by Mr Lemuel Gulliver in person, or rather in dramatis personae. They are the literary artifices through which Swift declares the truthfulness of his story, which is not only a satire of his contemporary England but also a satire of the human being, of history and historical accounts, of novels and romances. For this very reason, it is my belief, the two Italian translators decide to violently ma-

3 This passage exemplifies Taroni's attitude towards Swift's satire: he takes the liberty of changing every word, sentence, or passage that could have been unpleasant for the regime.

4 s.v. "romance." The Oxford English Dictionary. Ed. J. A. Simpson and E. S. C. Weiner. Vol. 14. Oxford: Clarendon Press, 1989. 
nipulate the source text so as not to displease the regime - "leftovers," omissions, and silences are always critical in understanding the workings of power in translation and in a culture (Gentzler and Tymoczko 2002).

In conclusion, by analysing translations of Gulliver's Travels during the Fascist regime, I have tried to bridge the gap between linguistic analysis and cultural history. Ideology emerges as an implicit component of the translation process at the root of self-censorship. The translation of Gulliver's Travels can therefore be seen, in tune with the latest theoretical debates, not only as a historical object but also as an approach to interpreting a historical subject (Munday 2014); in our case study, it has cast light on Italian cultural history and provided fascinating insights into Fascist policy.

\section{Works cited}

Billiani, Francesca. "Assessing Boundaries - Censorship and Translation: An Introduction." Modes of Censorship and Translation: National Context and Diverse Media. Ed. Billiani. London: Routledge, 2007. 1-26.

Bonsaver, Guido. Censorship and Literature in Fascist Italy. Toronto: University of Toronto Press, 2007.

Fabre, Giorgio. "Fascism, Censorship and Translation.” Modes of Censorship and Translation: National Context and Diverse Media. Ed. Francesca Billiani. Manchester: St. Jerome Publishing, 2007. 27-59.

Faggi, Adolfo. “I Viaggi di Gulliver.” Rivista d'Italia February 1913: 245-260.

Gentzler, Edwin, and Maria Tymoczko, eds. Translation and Power. Amherst and Boston: University of Massachusetts Press, 2002.

Gregori, Flavio. "The Italian Reception of Swift." The Reception of Jonathan Swift in Europe. Ed. Hermann Josef Real. London: Bloomsbury Academic, 2013. 17-56.

Martini, Esther. Jonathan Swift. Rimini: Garattoni, 1933.

Milic, Louis Tonko. A Quantitative Approach to the Style of Jonathan Swift. Paris: Mouton, 1967. Munday, Jeremy. "Using Primary Sources to Produce a Microhistory of Translation and Translators: Theoretical and Methodological Concerns." The Translator 20.1 (2014): 64-80.

Pagetti, Carlo. La fortuna di Swift in Italia. Bari: Adriatica Editrice, 1971.

Rabizzani, Giovanni. “L’uomo di Swift.” Il Marzocco 1 February 1914: 4.

Rebora, Pietro. Jonathan Swift. Rome: Formiggini, 1922.

Rundle, Christopher. Publishing Translations in Fascist Italy. Berne: Peter Lang, 2010.

Rundle, Christopher. "Theories and Methodologies of Translation History: The Value of an Interdisciplinary Approach.” The Translator 20.1 (2014): 2-8.

Swift, Jonathan. I viaggi di Gulliver. Ed. and trans. Carlo Formichi. Milan: Mondadori, 1933.

Swift, Jonathan. I viaggi di Gulliver. Ed. and trans. Luigi Taroni. Sesto San Giovanni: Edizioni A. Barion della Casa per le Edizioni Popolari, 1934.

Swift, Jonathan. Gulliver's Travels. The Cambridge Edition of the Works of Jonathan Swift. Vol. 16. Ed. David Womersley. Cambridge: Cambridge University Press, 2012.

Woolley, David, ed. The Correspondence of Jonathan Swift, D.D. Frankfurt am Main: Lang, 1999. 
Elisa Fortunato is a research fellow in Language and Translation - English Language at the University of Bari. The main area of interest in her research is represented by the language of irony in the eighteenth century and the rhetoric of history in the eighteenth and nineteenth centuries. She has published essays on classical sources of Gulliver's Travels, a book in 2014 (Le trace del marinaio: Note ai "Gulliver's Travels" di Jonathan Swift), and on the relationship between history and fiction in the English nineteenth century. Since 2015, she has been studying the relationship between translation and patronage during Fascism. She has translated the novel History and Adventures of an Atom by T. G. Smollett (2010). 